\title{
Examining the Effectiveness of Teamwork in Work Engagement among Gen Y-A Conceptual Framework
}

\author{
Sreenivasan Jayashree, C.A. Malarvizhi, Mohammad Nurul Hassan Reza, Shalini Baskiran
}

\begin{abstract}
As the older generation is retiring from the workforce, it became a concern for many organizations on ways to manage the new generation who is flowing into the current workforce. This new generation is known as Gen Y. This generation workforce often linked to job hopping and their loyalty towards the organization is being questioned by researchers as many organizations are experiencing a high level of attrition among them. This study investigated teamwork as a critical success factor of work engagement among Gen Y. The methodology adopted in this study includes an extensive review of the literature on teamwork that contributes to working engagement, followed by questionnaire distribution and then the answers were processed and statistically measured and analyzed. The results of this study conclude that there is a significant positive relationship between teamwork, work engagement and IR 4.0. The practical implications of the study will be useful for the organization to address and examine the effect of teamwork that influences work engagement to reduce high turnover among Gen Y employees.
\end{abstract}

Keywords: Gen Y, Work Engagement, Teamwork.

\section{INTRODUCTION}

The Baby Boomers, Generation X or Gen X and Gen Y are the three generations which are still active in the workforce (Pyoria, Ojala, Saari \& Jarvinen, 2017). Baby Boomers comprises of those who were born between the years 1946 to 1964 while Gen X are those who were born between the years 1965 to 1979 (Sharkawi, Mohamed \& Roslin, 2016). Over the last decade, the term employee engagement has received great attention in organizations (Mun, Suhaimi, Abdullah, Rahman \& Mat, 2012). The term employee engagement or work engagement can be used interchangeably (Schaufeli \& Witte, 2017) which can be defined as the involvement and enthusiasm of an employee in his or her job which would create positive influence on their workplace (Mun et. al., 2012). The impact of work engagement is an essential study in organizational management as it comprises of highly engaged employees who can intensively contribute to productivity, innovation

Revised Manuscript Received on September 22, 2019

Sreenivasan Jayashree, Faculty of Management, Multimedia University, Cyberjaya, Malaysia.

C.A. Malarvizhi, Faculty of Management, Multimedia University, Cyberjaya, Malaysia.

Mohammad Nurul Hassan Reza, Faculty of Management, Multimedia University, Cyberjaya, Malaysia.

Shalini Baskiran, Faculty of Management, Multimedia University, Cyberjaya, Malaysia. and performance while minimizing cost related to retention and recruitment in an organization (Mansoor \& Hassan, 2016). Therefore, it would be easy if organizations make efforts to understand the expectation of Generation $\mathrm{Y}$ in order to emulate those factors and manage this generation more effectively. Hence, this study which aims to focus on the Malaysian perspective particularly on the critical success factors of work engagement among Gen Y in Malaysia. The research will explore teamwork as one of the important factors of work engagement among Gen Y.

This study also investigates that, team work can significantly assess IR 4.0. The majority of Gen-Y staffs need their work to come with a good judgment of rationale. Linking with the related generation, most of whom are familiar to rapid answers and real-time responds online, should be enhanced through steady engagement and reaction that assists them discover and develop along the way. This would go an extended way in appealing and maintaining fresh talent. Limit in discover the appropriate talent and expertise shortage can slow down the industry transition and the entry to IR 4.0. So, the organizations in Malaysia should consider this issue to enter into the fourth industrial revolution.

According to Lauren Vesty (2016) survey, organizations and staffs can together benefit from jointly creating a meaningful work environment. The survey explored that, if a enterprise can assist persons better find purpose at job place, then the company will benefit from having more productive and winning staffs. Person's view on purpose is significantly affected by his/her age and experience. This is why, teamwork in organizations should be developed to engage the Gen Y employees in order to achieve the highest level of productivity and thus enterprises can enter into the era of IR 4.0.

\section{A. Background of the Research}

Researchers revealed that differences in work related value among generations influence their work engagement (Singh \& Gupta, 2015). The significance of work engagement in current business environment shouldn't be neglected as multigenerational workforce creates a serious challenge in work engagement (Lenka \& Naim, 2015).

According to the Malaysia Statistical Department, 50 percent of current workforce is from Gen $\mathrm{Y}$ and this generation will have to fill up almost three quarter of the 
universal labor force (Jefri \& Daud, 2016). As generation Y will play a significant role in employment market they are the future leader of the country's financial growth.

\section{1) Research Question}

Followed by above discussion, this research needs to explore the relationship between teamwork and work engagement of Gen Y employees in Malaysia. Therefore, this study should answer following questions:

- What is the relationship between Teamwork and Gen Y Work Engagement?

\section{2) Research Objective}

Supporting with the research questions and research problem this study intends to explore-

- The relationship between Teamwork and Gen Y Work Engagement

\section{LITERATURE REVIEW}

Currently organizations are experiencing retirement of older employees and replacement with the latest generation entering the workforce (Twenge et al., 2010). In Malaysia over 50\% of the workforce constitutes of Gen Y (Queiri et. al., 2014) whereas Baby Boomers are approaching retirement and by the year 2025 it is predicted that around $20 \%$ of Gen X will be retiring (Sharkawi et. al., 2016) As Gen Y emerges as a big cohort in the labor market, the attraction and retention of them is vital for any organization to sustain and grow (Shah, 2017).

Statistics exhibit that approximately $62 \%$ of Malaysian Gen Y whom were ex-employees in Malaysian organization, migrated to Singapore and Australia. If this situation continues, it will be a threat to the country in terms of financial expansion in the long run (Queiri et al., 2015). Relating to the issue above, studies suggested that having engaged employees', benefits organization in terms of reducing training costs for new employees since high retention can be only achieve when employees are highly engaged (Liyanage \& Gamage, 2017).

\section{A. Gen Y}

The people who were born between the years 1980 to 1999 are called Generation Y or in short Gen Y. They are also commonly known as Millennial. Other terms for them includes: 'The Next Generation', the 'Dot-Coms', the 'Echo-Boomers', the 'I-Generation', the 'Me Generation', 'Generation-D' (digital), and the 'Nexters' (Srivastava, 2013). This generation cohort is predominantly characterized for having high levels of self-reliance, self-confidence, autonomous, individualistic, and socially active and enjoys working in group (Ozelik, 2015).

This is partly due to the reason that they belong to nurturing and protective parents who entertains and treats each and every of their children's' emotional, educational and physical needs (Ozelik, 2015) which is possible because generally Gen Y comes from a family where the both parents are working (Sharkawi et. al., 2016). Furthermore, Gen Y individuals are familiar in getting help through social network, let it be to make decisions or to gain information and spread their experiences. Since they are often connected with each other, they tend to learn quickly especially the way they process information as compared to the previous generations (Zarim \& Zaki, 2015).

In context of Malaysian Gen Y, turnover becoming much of a worrying issue as the country is already facing shortage of talent. This serious issue may be worsening in coming years if there is lack of understanding in the demand of Gen $\mathrm{Y}$ at work.

\section{B. Work Engagement}

Work environment is a compulsory place that a company provides to their employees. It is also an atmosphere to support employees to engage better when the company manages to create surroundings that influence the employees (Anitha \& Aruna, 2016). Providing a good work environment to employees is so important because this is a way to create possibility for redress of basic psychological drives to attain one's potential, because an employee relatively spend large portion of their time at workplace.

The studies also further suggested that fulfillment of psychological requirements at work is very important to develop one's work engagement besides providing intrinsic motivation (Ray Markey, Katherine Ravenswood \& Don Webber, 2012).

according to Mohd, Shah \& Zailan (2016) an individual feels safe in an organization which has open and supportive environment, because this kind of environment encourages workers to experiment and try out new things without having the fear of the consequence even they if fail. An organization that caters according to the employees need and feelings are considered as a management that fosters a supportive working environment.

\section{Teamwork}

Teamwork can be stated "as a cooperative process that allows ordinary people to achieve extraordinary results". In detail, teamwork means a team that has a common goal or clear objective where members in the team create successful, mutual relationship to gain team purpose by sharing knowledge and talents (Tarricone \& Luca, 2002). Research of Chien, Wan \& Chen (2012) has also mentioned in their studies that teamwork is observed as group member working mutually to accomplish a common goal and the most important thing to make this work is that members should have mutual awareness. Mutual awareness includes their perception about communication, work climate, safety culture and work pressure which will enable them to carry out team work lucratively. Members in a team should be flexible to adapt to cooperative working environment because the desired results can only be achieved through collaboration and social independence. Therefore, to have a successful teamwork depends on the synergy between the team members (Tarricone \& Luca, 2002).

Hypothesis for the study are as follows:

$\mathrm{H}$ : There is a significant and positive relationship between Teamwork and Work Engagement among Gen Y. 


\section{FRAMEWORK}

After an extensive literature review for the purpose of exploring the Teamwork that related to Gen Y employee work engagement, the research has arrived at a conceptual framework (Figure 1).

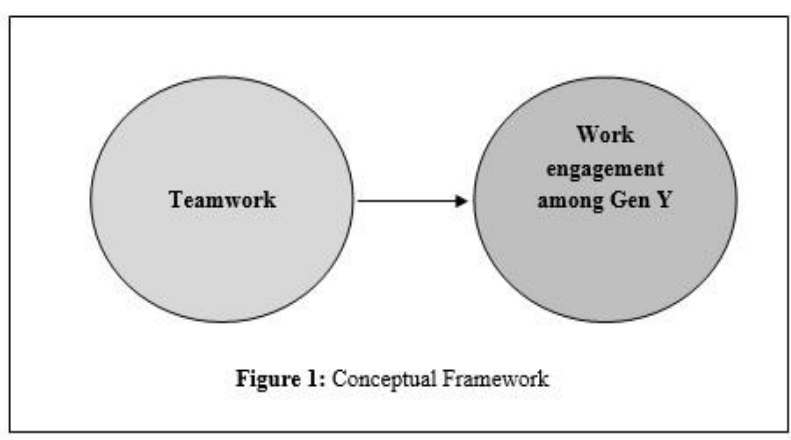

Fig 1: Conceptual Framework

\section{Methodology}

The population of this study will be a Malaysian working adult born between the years 1980 to 1999 . Questionnaires will be designed and administrated electronically by using Google form and will be distributed among respondents via WhatsApp and Facebook. The reliability of the data will be tested through Cronbach's Alpha. The outlier will be tested using the Mahalanobis test to ensure the data that being tested are free from outliers in order to provide accurate results.

Acknowledgement: We would like to express our cordial thanks to Ministry of Education, Malaysia for giving us an opportunity to carry out this project under FRGS grant.

\section{Conclusion}

This study contributes towards identifying the effect of teamwork in work engagement among Gen Y in Malaysia because identifying teamwork as a factor and the level of influence of the factor towards work engagement determines if the employees' productiveness and willingness to stay in the organization.

\section{REFERENCES}

[1] Anitha, J. \& Aruna, M., (2016). Enablers of Employee Engagement of Gen Y at the Workplace. Amity Journal of Training and Development, Vol 1.(1),p. 93-108.

[2] Berkup,S.B., (2014). Working with Generations X and Y in Generation $\mathrm{Z}$ Period: Management of Different Generations in Business Life. Mediterranean Journal of Social Sciences, Vol.5(19),p. 218-229.

[3] Biswakarma, G., (2016). Organizational Career Growth and Employeese Turnover Intentions: An empirical evidence from Nepalese Private. International Academic Journal of Organizational Behavior and Human Resource Management, Vol.3(2), p.10-26.

[4] Devi,R., Narayanamma,P.L., (2016). Impact of Leadership Style on Employee Engagement. Pacific Business Review International, Vol.1(1), p.91-98.

[5] Galetic, L., Klindzic, M. \& Braje, I.N., (2016). Millennials' Career Expectation: Exploring Attitudes and Individual Differences in Croatia. International Journal of Economics and Management Engineering, Vol.10(6), p.1876-1879

[6] Jefri, N.A.M., \& Daud.N (2016). Exploring Employee Retention among Gen Y in Oil and Gas Industry. International Academic Research Journal of Business and Technology, Vol .2(2), p.152-156.
[7] Khan, M.S., \& Pandey, S., (2016). A study of performance appraisal for generation Y: Issues and challenges. International Journal of Multidisciplinary Research and Development, Vol.3(9), p.228-230.

[8] Kmiotek,K., \& Kopertynska, M.W., (2015). Engagement of employees of generation $\mathrm{y}-$ theoretical issues and research experience. Argumenta oeconomica, Vol. 2(35), p.185-201.

[9] Lenka, U.\& Naim, M.F., (2015). Mentoring as an hr intervention to engage gen y employees. International Journal of Social Science, Vol.2(1), p.1697-1715.

[10] Mee,L.Y., Yin-Fah., B.C., \& Siew,H.K., (2016). Smiliraties and Diferrences of Work Values Between Gen X and Gen Y in Malaysia. International Business Mangement, Vol.10(9), p.1687-1692.

[11] Ozelik, G. (2015). Engagement and Retention of the Millennial Generation in the Workplace through Internal Branding . International Journal of Business and Management,Vol. 10(3), p.99-107.

[12] Pyoria,P., Ojala,S., Saari,T., Jarvinen,K.M., (2017). The Millennial Generation: A New Breed. Sage Open, 1-14

[13] Queiri, A., \& Dwaikat, N., (2016). Factors Affecting Generation Y Employees' Intention to Quit in Malaysian's Business Process Outsourcing Sector. Journal of Sustainable Development, Vol.9(2), p.78-92.

[14] Queiri, A., \& Dwaikat, N., (2016). Factors Affecting Generation Y Employees' Intention to Quit in Malaysian's Business Process Outsourcing Sector. Journal of Sustainable Development, Vol.9(2), p.78-92.

[15] San,L.Y Omar,A. \& Thurasamy,R., (2015). Online Purchase: A Study of Generation $\mathrm{Y}$ in Malaysia. International Journal of Business and Management, Vol.10(6),p. 1-7.

[16] Schullery, N. M. (2013). Workplace Engagement and Generational Differences in Values.Vol. 76(2),p. 252-265.

[17] Sharkawi,S., Mohamed,S.A.J.N.S \& Rosmimah Roslin (2016). Exploring the Leadership Preferences of Malaysian Geneartion Y Employees: A Conceptual Paper. International Journal of Business and Management,Vol. 11(8), p. 152-161.

[18] Sibarani,R.M., Tjakraatmadja, J. H., Putro U. S. \& Munir N. S.,(2015). The Influence of Multigenerational Workforce in Effective Informal Team Learning. Journal of Economics and Business Research, Vol.21(2),p. 199-217.

[19] Twenge,J.M., Campbell,S.M., HoffmanB.J., \& Lance, C.E., (2010) Generational Differences in Work Values: Leisureand Extrinsic Values Increasing, Social and Intrinsic Values Decreasing. Journal of Management, Vol 36(5), p.1117-1142.

[20] Westerman, J.W., \& Yamamura, J.H., (2007). Geneartional Preferences for Work Enviroment Fit: Effects on Employee Outcome. Career Development International, Vol 12 p.150-161.

[21] Yee,T.Y., \& Muthu,K., (2011). An analysis on workplace expectations among the white collar employees across Baby Boomers, Gen $\mathrm{X}$ and Gen Y in Malaysia. . Bangkok, Thailad: Sunway Uiversity, Malaysia

[22] Zarim,Z.A \& Zaki, H.O., (2015). Creating A Sense of Belonging For Gen Y at The Workplace. International Journal for Innovation Education and Research,Vol. 3(5), p.39-45

\section{AUTHORS PROFILE}

My name is Sreenivasan Jayashree, I am associate with Faculty of Management, Multimedia University, Cyberjaya, Malaysia and my research interest is management and social sciences.

C.A. Malarvizhi, I am associated with Faculty of Management, Multimedia University, Cyberjaya, Malaysia and my area of interest is management

I am Mohammad Nurul Hassan Reza, I am attached with Faculty of Management, Multimedia University, Cyberjaya, Malaysia.my area of interest is management and business studies.

My name is Shalini Baskiran, I am from Faculty of Management, Multimedia University, Cyberjaya, Malaysia.and my area of interest is management 